単軸圧縮応力を受けるコンファインドコンクリート内に配筋された

圧縮軸筋の座屈におよぼす諸要因の影響

コンファインドコンクリート内に配筋された圧縮軸筋の座屈に関する研究（その1）

\title{
EFFECTS OF FACTORS ON BUCKLING OF LONGITUDINAL REINFORCEMENT ARRANGED IN CONFINED CONCRETE UNDER UNIAXIAL COMPRESSION
}

Buckling of longitudinal reinforcement arranged in confined concrete (Part 1)

中塚 佶*, 中川裕史**, 阪井由尚**

Tadashi NAKATSUKA, Hiroshi NAKAGAWA and Yoshitaka SAKAI

\begin{abstract}
This paper describes effects of factors on strains at buckling of longitudinal reinforcement within confined concrete subjected to uniaxial compression. Experimental variables employed in this study were ratios of lateral reinforcement pitches to specimen diameters (S/D), an index of confining stress (Ps $\sigma$ sy), yield strength of the lateral reinforcement ( $\sigma$ sy), compressive strength of plain concrete (Fo), and shapes of the lateral reinforcement. Test specimens were cylindrical specimens with $200 \mathrm{~mm}$ diameter and prismatic specimens with sections of $200 \times 200 \mathrm{~mm}$, both of which were $600 \mathrm{~mm}$ in height and without cover. The following conclusions can be obtained mainly.

1) Clear definition on strains at buckling of longitudinal reinforcement are proposed on the basis of axial force decrease of longitudinal reinforcement calculated from data of lateral deformation of the reinforcement.

2) Because buckling of longitudinal reinforcement is considered to depend on behavior of confined concrete, variables which make mechanical performance of confined concrete higher, such as smaller pitch and larger amount of lateral reinforcement, lower concrete strength, etc, increase the buckling strains.
\end{abstract}

Keywords: compressive longitudinal reinforcement, buckling, confined concrete, definition of the buckling, strain at buckling

圧縮軸筋, 座屈, コンファインドコンクリート, 座屈の定義, 座屈時ひずみ

\section{1. 序論}

構造部材のエネルギー吸収能力に基盤をおく耐震設計法では、 部材の終局変形能力の明確な評価方法とその改善方法の確立 が不可欠である。

コンクリート構造における曲げ部材の終局変形能力は、曲げ圧 縮域にコンファインドコンクリートを適用することによって、顕著に 改善されることが、実験的および解析的に明らかにされ、同方法 を用いた設計法の提案も行われている ${ }^{1) ~ 4) ~}$

一方、同曲げ部材の終局変形能力を評価するには終局限界点 の設定が必要であるが、その曲げ終局限界点として、1)〜4)など が提案されている5)。

1）部材断面内での曲げ圧縮合力が、コンクリートのひずみ軟化 性質のため、曲率の増大に対して増加、あるいは一定值を保 つ引張側鋼材合力を支持できなくなる限界点

2）引張主筋が破断する限界点

3）圧縮主筋が座屈する限界点

4）曲げ圧縮域におけるコンファインドコンクリートの横補強筋 が破断する限界点

特に、3)の「圧縮主筋の座屈」は、これまでに行われてきた数多 くの水平加力を受ける鉄筋コンクリート柱部材の実験結果、およ
び地震による鉄筋コンクリート柱部材の破壊状況などからも明ら かのように、鉄筋コンクリート部材の曲げ終局破壊に対する一つ の重要な要因である。言い換えれば、軸筋の座屈は、a)曲げ圧 縮合力の低下を生じさせるだけでなく、b)その顕著な屈曲変形に よる横補強筋の破断、さらには、c)逆方向荷重時に作用する引張 力によって主筋自身の破断を引き起こすなど、兵庫県南部地震 における夥しい震害例を示すまでもなく、鉄䈘コンクリート部材の 曲げ終局破壊に対する1つの重要な要因である。

圧縮軸筋の座屈について次のような研究が行われている。

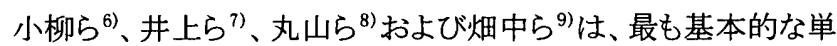
調圧縮荷重下の鉄筋コンクリート柱部材において、横補強筋の 間隔と径および軸筋の直径などを変数とした実験研究から、また、 加藤ら ${ }^{10}$ は、軸筋および横補強筋の降伏強度、配置位置などを 個々に変数とした実験研究より、圧縮軸筋の座屈におよぼす諸 要因の影響を調べている。しかし、いずれの研究においても、各 種要因の水準範囲が限られており、また、2.1 項で述べる軸筋の 座屈時の定義の不明確さと相まって、圧縮軸筋の座屈挙動が十 分に明らかになっているとは言い難い。

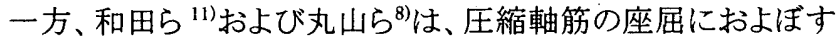
諸要因の影響を解析的に検討している。しかし、それらの研究で

$*$ 大阪大学工学部建築工学科 講師 $\cdot$ 工博

**束急建設設計本部構造設計部

Assist. Prof., Dept. of Architectural Eng. Fac. of Eng., Univ. of Osaka, Dr. Eng. Dept. of Structure Design, Tokyu Construction Co., Ltd. 
は、軸筋の座屈に極めて大きな影響を与えると思われる、圧縮応 カ下のコンクリートが示す横方向膨張特性、ならびに座屈長さに 影響を与えるコンクリートの破壊領域の大きさなどが考慮されてい ないという問題点を持っている。

本研究は、横補強筋が軸筋の座屈を直接拘束するという前述 した諸研究での立場とは異なる観点に立つものである。すなわち、 コンファインドコンクリート内に配筋された軸筋の挙動は、同コンク リートの性能に密接に関係するというスタンスから、軸筋の座屈挙 動を調べようとするものである。その理由は、コンクリート内に配筋 された普通強度の軸筋は、圧縮強度時ひずみが $0.2 \%$ 程度のプ レーンコンクリートの場合でも、終局変形能力時には全塑性化す ると考えられるため、座屈と密接に関係する軸筋の横方向変形は、 軸筋周囲のコンクリートの横方向変形特性に大きく依存すると推 測されることによる。

それ故、本研究では、コンファインドコンクリートについての基本 的な影響要因を変数と寸る広範囲な実験研究を行い、軸筋の支 持耐力低下時という明確な定義による座屈時ひずみに対する諸 要因の影響を明らかにすることを試みた。

\section{2. 軸筋の座屈時の定義}

\section{1 既往の研究における定義}

軸筋座屈におよぼす諸要因の影響を明らかにして、その定量 化を図るためには、座屈の明確な定義が不可欠である。しかし、 既往の研究では以下に示すような各種の定義が用いられており、 確立したものはない。

小柳 $\zeta^{6}$ は、試験体の荷重一変形曲線における勾配の変化点 と、軸筋座屈の目視による確認点との対応から同変化点を座屈 時としているが、判定の恣意性に問題があると思われる。また井 上ら ${ }^{7)}$ は、荷重一変形曲線の接線勾配の極大点時を座屈時と定 義する、後述する筆者らと同様の方法を用いている。これに対し、 丸山ら ${ }^{8}$ は、コアコンクリートの反対側で軸筋に貼付したひずみ ゲージの測定值が、軸筋の屈曲によって戻り始める時点を座屈 点として与えている。この方法は座屈開始を捉える有効な方法と 考えられるが、試験体の中で座屈が開始し始める位置を予め知 ることは極めて困難である。加藤ら ${ }^{10)}$ は、軸笳の負担軸力がひず み硬化後に再び降伏応力度まで低下した時点を座屈時と定義し ているが、明確な物理的根拠および理由は不明である。村山ら ${ }^{12)}$ は、局部焼き入れ部分において直接測定した軸筋の圧縮応力が、 試験柱の曲率の単調変化時において増加から減少に転じる時 点を座屈時と明快に定義している。しかし、丸山らの場合と同様、 局部焼き入れ部分と座屈開始位置との対応づけに困難さがある と思われる。

筆者らは、座屈は軸筋の支持耐力を低下させるという観点から、 試験体の荷重一変形曲線における接線勾配の変化点を座屈時 と定義する方法を最初に提示し ${ }^{13)}$ 、その後、軸筋自身の屈曲変 形の急激な増分変化性状を加味する、より推定精度の高い方法

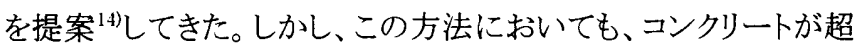
高強度などで、試験体の全圧縮荷重に占める軸筋の支持耐力 の割合が相対的に小さい場合には、軸筋の支持耐力低下点、す
なわち軸筋の座屈時の判定が難しくなる傾向が見られた ${ }^{15)}$ 。

\section{2 本研究における定莪}

軸筋の支持耐力の低下、あるいは軸ひずみの戻りから直接的 に軸筋の座屈時を定義および判定することが最も明快であると思 われる。しかし、前述したように軸筋の座屈開始位置を予め知るこ とは極めて困難である。

したがって、本研究では、軸筋の局部ひずみを追跡する方法で はなく、軸筋の全体的な屈曲状況から座屈時を推定する方法を 採用した。すなわち、軸筋の横方向変位測定値から屈曲曲線を 推定し、同曲線における最大横変位位置を座屈開始位置、およ びその位置における断面縁ひずみの戻り開始推定時点を、軸䈘 の座屈時と判定する方法を採用した。

図1は、後述する本実験における試験体の軸筋の横方向変位 の測定結果例である。すなわち、同図中に添え図として示した試 験体の荷重 $(P)$ 一ひずみ $(\varepsilon)$ 関係での各載荷ステップにおける軸 筋の横方向変位 $\delta\left(=\sqrt{\delta x^{2}+\delta y^{2}}: \delta \mathrm{x}, \delta \mathrm{y}\right.$;直交 2 方向での 測定值)の材軸方向についての測定結果の一例である。同図に よれば軸筋の屈曲の状況は、いずれの載荷ステップにおいても、 座屈長さ測定値 $(l)$ を半波長とする $\sin$ 曲線で良好に近似できる と判断される。それ故、軸筋の横方向変位 $(\delta)$ の材軸方向の
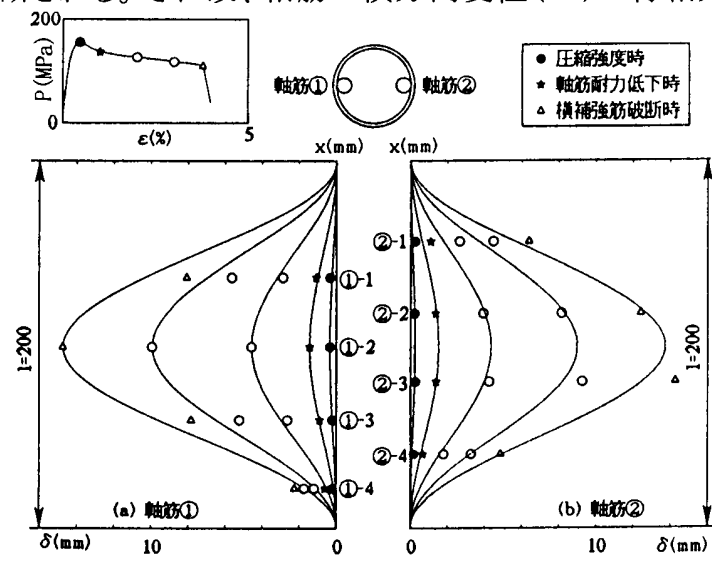

図 1 軸筋横方向変位の材軸方向の分布 [試験体:F3Y4C3D19P2C]

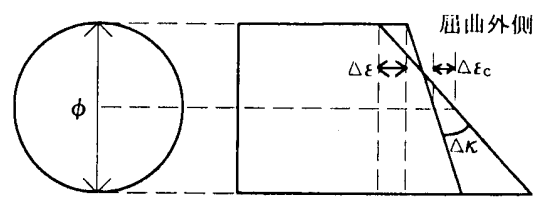

図 2 軸笳断面のひずみ分布

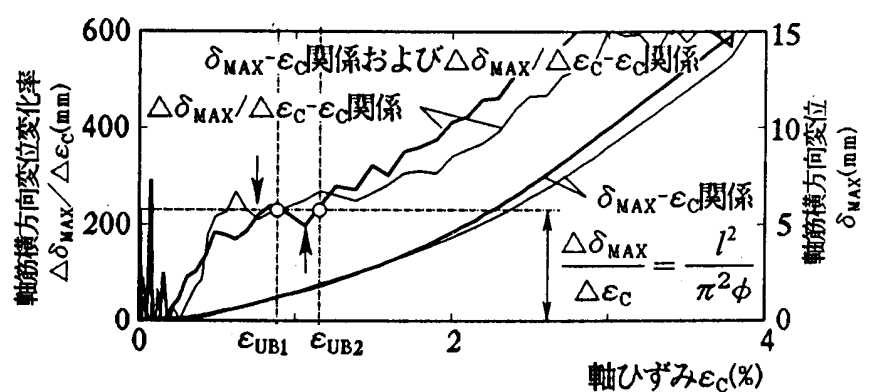

図 3 軸筋耐力低下点の判定の一例 [試験体:F3Y4C3D19P2C] 
分布を $x=l / 2$ で $\delta \max$ とな(1)式で近似し、同式に、ある測定 位置とそこにおける横方向変位測定值 $(\mathrm{x}, \delta(\mathrm{x})$;ここでは测定横 方向変位の最大位置を採用)を代入すれば、各載荷レベルにお ける屈曲曲線、具体的には $\delta$ maxとその位置が推定できることに なる。また、たわみと曲率の関係から、屈曲曲線が(1)式で近似さ れる場合、軸筋の断面曲率は $\delta \max$ 位置で最大值 $\kappa$ maxを示し、 両者の関係は(2)式で与えられる。

$$
\begin{aligned}
& \delta(x)=\frac{1}{2} \delta_{\max } \sin \left(\frac{2 \pi x}{l}-\frac{\pi}{2}\right)+\frac{1}{2} \delta_{\max } \quad(0<x<l) \\
& \kappa_{\max }=\kappa\left(\frac{l}{2}\right)=\frac{2 \pi^{2}}{l^{2}} \delta_{\max }
\end{aligned}
$$

次に、座屈時の判定条件について述べる。図2は圧縮力を受

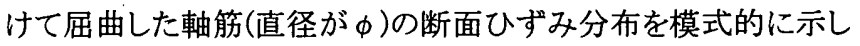
たものである。同図によれば、圧縮軸ひずみ增分 $\Delta \varepsilon c$ と曲げ変 形による曲率変化 $\Delta \kappa$ が生じた状態下での小さい方の断面縁ひ ずみ増分 $\Delta \varepsilon$ は(3)式で与えられる。

$$
\Delta \varepsilon=\Delta \varepsilon_{C}-\frac{\phi}{2} \Delta \kappa
$$

ここで、 $\Delta \varepsilon$ が負になると、すなわち、コンクリートの横拘束の程 度によって変化するコンクリートの横膨張変形、および屈曲による

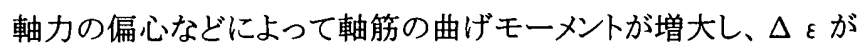
負となり断面縁ひずみの戻りが生じると、軸等負担力の減少が生 じ、座屈時と判定される。したがって、座屈時の判定条件式は、 (3)式の右辺に推定屈曲曲線の $\delta$ max位置における曲率増分 $\Delta$ $\kappa \max$ 代入して、 $\Delta \varepsilon<0$ とすることから(4.1)式のように得られる。 さらに同式は(2)式の関係を用いると(4.2)式となる。なお、(4)式に おいて座屈長さ $l$ は、測定值のバラツキによる影響を避けるため、 測定結果を整理して得られた座屈長さと軸筋の関係 ${ }^{13)}$ による推 定值 (D13,D19,D25に対し $l=160 \mathrm{~mm}, 200 \mathrm{~mm}$,および250mm)を用 いた。

$$
\frac{\Delta \kappa_{\max }}{\Delta \varepsilon_{c}}>\frac{2}{\phi} \text { (4.1) または } \frac{\Delta \delta_{\max }}{\Delta \varepsilon_{c}}>\frac{l^{2}}{\pi^{2} \phi}
$$

図3に、(4.2)式による軸笳耐力低下点の判定の一例を示す。同 図は、同一試験体に配筋された 2 本の軸筋の $\delta \max -\varepsilon c$ 関係、 および $\Delta \delta \max / \Delta \varepsilon \mathrm{c}-\varepsilon \mathrm{c}$ 関係を示したものである。同図中 に(4.2)式の不等号を等号とした直線を併記しているが、座屈時は 同直線と $\Delta \delta \max / \Delta \varepsilon c-\varepsilon c$ 関係との交点(O印)で明快に 判定できることが分かる。なお、 $\Delta \delta \max / \Delta \varepsilon c-\varepsilon c$ 関係には バラツキがあるため、座屈時としては最も大きい $\varepsilon \mathrm{c}$ となる交点を 採用している。また、本方法による軸筋の座屈時は文献 13)に示
す筆者らの既往の判定法で用いていた、 $\Delta \delta \max / \Delta \varepsilon c-\varepsilon c$ 関係における公配の変化点 (同図中」印) ともほぼ一致している。

\section{3. 実験概要}

実験は、表1に示すように3つのシリーズで構成され、コンファイ ンドコンクリートについての基本的影響要因である、横補強筋の 間隔、形状、拘束応力指標(Ps $\sigma s y)^{16)}$ 、降伏強度およびコンク リート強度ならびに軸筋の直径を実験変数として取り上げた。

実験 1 は、横補強筋位置で一様な拘束力が与えられる、基本と なる円形横補強筋の場合において、軸筋の座屈時ひずみにおよ ぼす、横補強筋間隔比 $(S / D=0.1,0.2,0.35,0.7,1.0)$ 、拘束忘 力指標 (Ps $\sigma \mathrm{sy}=3.0,5.5,8.0 \mathrm{MPa})$ および軸筋の直径 (D13，D19, D25）の影響を調べるものである。ここでは、コンクリート強度およ び横補強笳降伏強度はそれぞれ一定とし、30MPa級および $400 \mathrm{MPa}$ 級のものを用いた。実験2では、軸筋の座屈時ひずみに およぼす材料強度の影響、すなわちコンクリート強度 $\left(\mathrm{F}_{\mathrm{O}}=30,60\right.$, $90 \mathrm{MPa}$ 級) および横補強筋降伏強度 ( $\sigma$ s $y=400,800,1300 \mathrm{MPa}$ 級)の影響を、円形横補強筋の場合において調べている。実験 3 では、角形横補強䈘の形状 (口型, 囲型) と降伏強度、およびコ ンクリート強度が軸筋の座屈時ひずみにおよぼす影響を調べて いる。

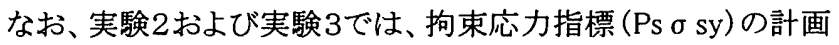
值および横補強筋間隔比 (S/D)をそれぞれ $5.5 \mathrm{MPaおよび0.2の}$ 一定とした。これは、標準的な大きさの柱部材において、普通強 度から高強度な鉄筋を用いるとしたときに、勒性確保に必要なPs $\sigma \mathrm{sy}$ の平均的な值、ならびにS/Dの上限的な值にそれぞれ対応 している。

試験体は図4に示すように、外径が200mmの円形断面 (実験 1 および実験2)ならびに $200 \times 200 \mathrm{~mm}$ の角形断面 (実験3)をもつ、 高さが $600 \mathrm{~mm}$ のかぶりコンクリートをもたない柱試験体である。試 験区間は試験体中央部の $400 \mathrm{~mm}$ 区間で、その両端にある $100 \mathrm{~mm}$ の端部領域には約 $20 \mathrm{~mm}$ のピッチで横補強筋を配筋し、またコン クリート打設側の上端面にはセメントペーストによるキャッピングを 施した。なお、本試験体はかぶりコンクリートを有しないが、これは 以下のような理由による。すなわち、プレーンコンクリートであるか ぶり部は軸筋座屈時に比べ、早期なひずみ段階で圧壊するため、 座屈におよぼす影響は小さいと考えたこと、また、かぶりのない基 本的な状態での軸筋の座屈挙動に注目したことによる。

使用した軸筋は、図5に示すように、いずれも表1に示される降 伏強度をもつ、明確な降伏棚を有するものである。また、横補強 筋は、PC鋼棒用ラインで製造した各種直径を有するほぼ真円断 面の線材に、熱処理を施して所定の降伏点強度としたもので製 作した、円形スパイラル筋および閉鎖型角形横補強筋である。 ンクリートは、セメント、細骨材および粗骨材としてそれぞれポルト ランドセメント、最大粒径 $20 \mathrm{~mm}$ の砕石および最大粒径 $5 \mathrm{~mm}$ の砕 砂を用いた、表 $2 に$ 示す調合をもつものである。使用した材料の 力学特性は表1中に併記している。

図6に載荷および測定方法を示す。載荷は $5 \mathrm{MN}$ 圧縮試験機を 用いて行い、載荷速度は手動調節した。また、球座は載荷荷重 
の偏心を取り除いた後に固定した。試験体の軸ひずみは、図4に 示すように、試験体中央の $400 \mathrm{~mm}$ 区間を測定検長として、ダイヤ ルゲージ式変位変換器を用いて測定した。軸筋の横方向変位の 測定は、試験区間の数力所で露出させた軸筋部分に点溶接した 金具に互いに90度をなす2本のインバー線を緊結し、その他端で ダイヤルダージ式変位変換器を用いて行った。また、横補強筋の 局部に作用する曲げモーメントと軸力を測定するため、コアコンク リート側 (内側) と外側の対称位置に検長 $2 \mathrm{~mm}$ の箔ゲージをそれ ぞれ貼付した。

\section{4. 軸筋の座屈におよぽす諸要因の影響}

図7〜12に、取り上げた諸要因をそれぞれ変数とする試験体の グループ毎に、試験体の荷重一軸ひずみ一軸筋横方向変位関 係、および横補強筋の局部に作用する曲げモーメント(M)と軸力 (N)の無次元化関係 (M/ $\pi r^{3} \sigma$ syとN/ $\pi r^{2} \sigma$ syの関係)をそれぞ れまとめて示す。ここで、軸ひずみは検長 $400 \mathrm{~mm}$ 区閒での平均ひ ずみ、軸筋の横方向変位は2.2項で述べた、各載荷ステップにお ける軸筋の屈曲変形の近似化から得られる最大横方向変位量 （ $\delta$ max）である。また、横補強筋の無次元化M-N関係は、 $\delta$ max

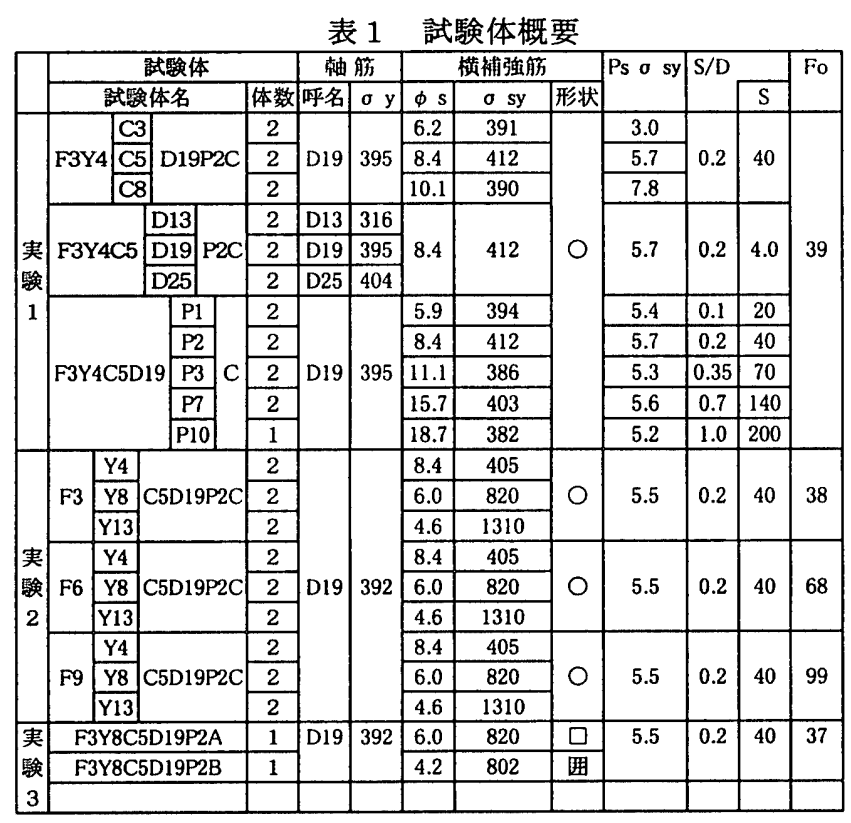

試験体名:F3 Y8 C5 D19 P2 A

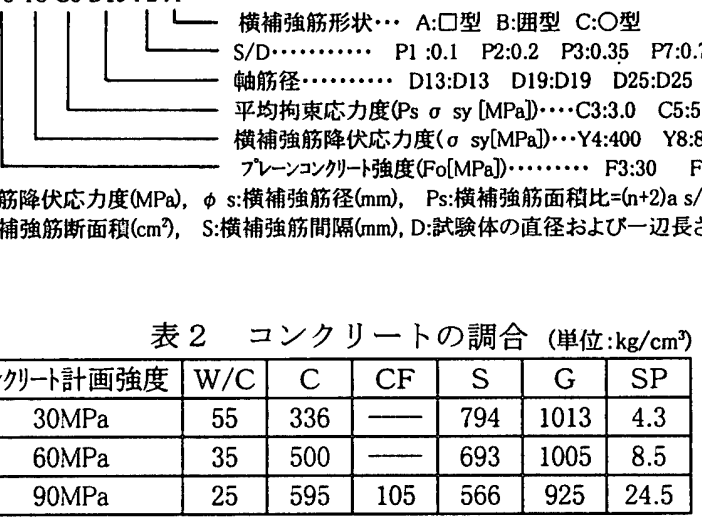

W/C:水セメント比(\%),C:セメント, CF:シリカヒューム S:細骨材，G:粗骨材，SP:高性能減水放(レオピルトSP-8HS)
位置に最も近い位置で得られたものである。なお、図7〜12中に おける白拔きの記号 $(O, \square, \triangle, \diamond, \nabla)$ は、2.2項の方法により推定 された軸筋の座屈時点を示す。黒印の記号

は、試験体の最大強度時点を示す。無次元化M-N関係には、横

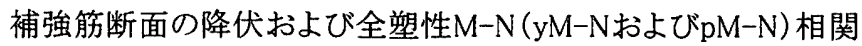
関係も併記している。なお、同一種の試験体では、ほぼ同様の荷 重一軸ひずみ一軸筋横方向変位関係、横補強筋の軸力一曲げ モーメント関係などが得られたので、図7〜図12には、平均的な 結果を代表として示している。
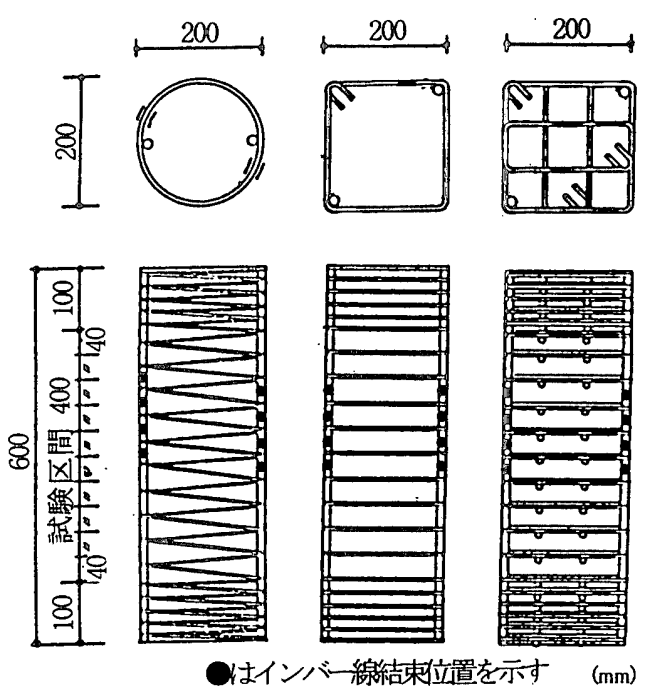

図 4 試験体配筋図

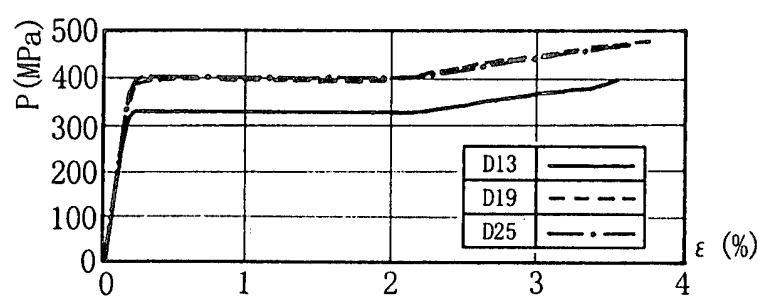

図 5 軸筋の引張応力度一ひずみ度関係

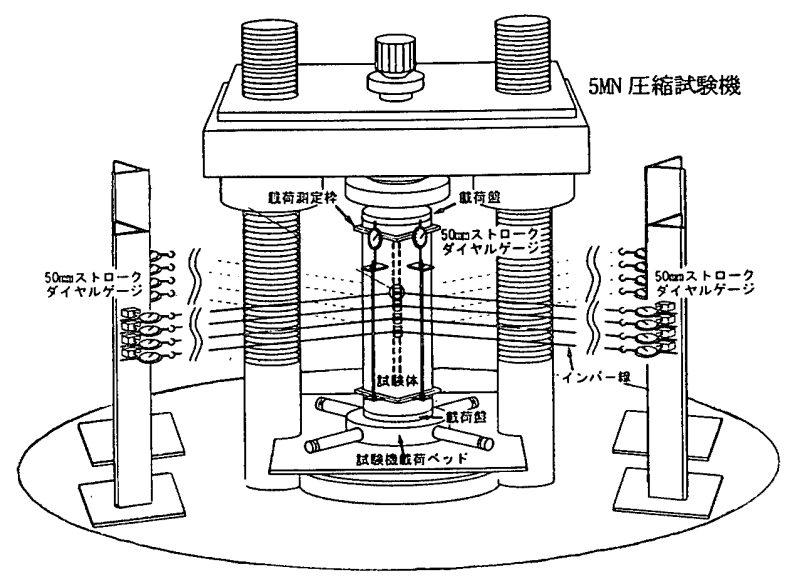

図 6 載荷および測定方法 


\subsection{S/Dの影響}

図7は、基本となる円形横補強筋を対象とした実験 1 で、同量 のPs $\sigma$ syおよび同径の軸筋を有する試験体を用いて、軸筋座屈 におよぼす横補強筋間隔の影響を調べた結果である。

Ps $\sigma$ syが同じために、太い横補強筋を粗いピッチで配筋した $S / D か ゙ 1.0 の$ 試験体の場合、最大強度(ピ一ク点)後、脆性的に破 壊して軸筋の横方向変形が急激に增加し、軸筋の座屈時は最 大強度時で与えられた。また、横補強筋断面の忘力状態を無次 元化による $(\mathrm{M}, \mathrm{N})$ 関係で示した同図(b)によれば、本試験体 $(\nabla$ 印)では横補強笳断面の $(M, N)$ 応力状態は最終段階まで弾性域 に留まっており、横補強筋は軸筋およびコンクリートに対し十分な 拘束効果を発揮していない。

$S / D か ゙ 0.7 の$ 場合、同じ軸ひずみ時における軸筋の横方向変位 は、S/Dが1.0の場合に比べ抑制されており、軸筋の座屈時は試 験体の最大強度(ピーク点)時を少し超えた段階となった。しかし、 同図(b)によれば本ケースの場合でも、座屈時(○印)における横 補強筋断面の $(\mathrm{M}, \mathrm{N})$ 忘力状態は弾性状態にあり、横補強筋の拘 束効率としてはまだ低い。なお、S/Dが0.7の本試験体の場合、横 補強筋の間隔は $14 \mathrm{~cm}$ で、主筋径 (D19)の約7倍程度と、指針等 17)で座屈防止のための規定值とほぼ同程度の值であるが、横補 強筋による主筋の座屈防止作用としては、上之園らも指摘する ${ }^{18}$ ように十分とは言えない結果となっている。

S/Dが0.35の場合、図7(a)に示されるように、最大強度(ピーク 点)時以降においても軸ひずみ増分に対する横方向変位の増加

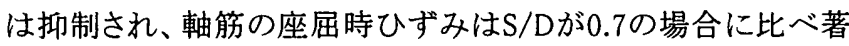
しく増加している。横補強笳断面の $(\mathrm{M}, \mathrm{N})$ 応力状態も同図(b)に 示されるように、試験体の最大強度(ピーク点)時には全塑性状態 に漸近し、また座屈時には $\mathrm{pM}-\mathrm{N}$ 曲線に達しており、横補強筋の 拘束効果は十分に発揮されていると判断される。なお、S/Dが 0.35 程度となると試験体の荷重一軸ひずみ関係は顕著に粘り強 いものとなるが、これは、コンファインドコンクリートとして粘り強いも のに変化してきたことを示すものと考えられる。

S/Dが0.2以下の場合、軸筋の横方向変形は一層抑制され、軸 筋の座屈時ひずみは一層大きなものとなる。また、横補強筋断面 の $(\mathrm{M}, \mathrm{N})$ 応力状態も図 $7(\mathrm{~b})$ に示すように、試験体の最大強度 (ピーク点)時からほとんど全塑性化しているので、軸筋の横方向 変位はコンファインドコンクリートの横方向変位とほぼ同様の挙動 を示していると推測される。

\subsection{Ps $\sigma$ syの影響}

図8は、Ps $\sigma$ syのみが異なる円形試験体の結果を比較したもの である。同図(b)によれば、S/Dは0.2と横補強筋間隔が小さいた め、いずれの試験体の場合でも、横補強筋断面の $(\mathrm{M}, \mathrm{N})$ 状態は、 試験体の最大強度(ピーク点)時には全塑性化し十分に横拘束効 果を発揮している。したがって、拘束応力指標が大きい場合ほど、 コンクリートの横膨張変形は十分に拘束される。その結果、同じ 軸ひずみ度における軸筋の横方向変形も顕著に減少し、かつ $\Delta$ $\delta \max / \Delta \varepsilon c$ も減少するため、軸筋の座屈時ひずみは増大した。 (試験体F3Y4C8D19P2Cでは、軸ひずみ6\%においても軸筋の 座屈は生じなかった。)

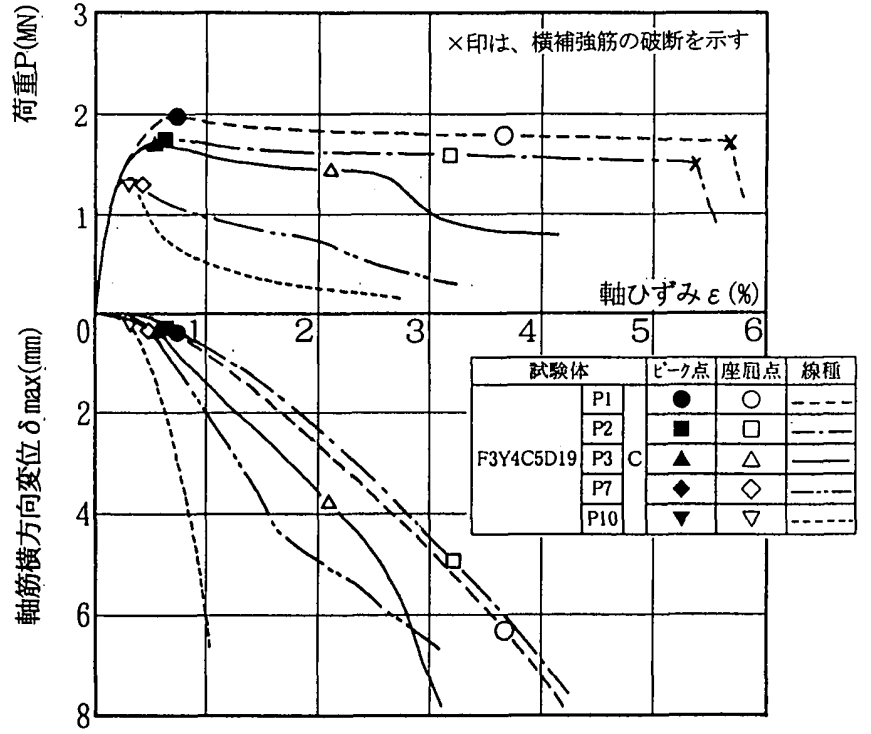

（a）荷重一軸ひずみ一軸筋横方向変位関係

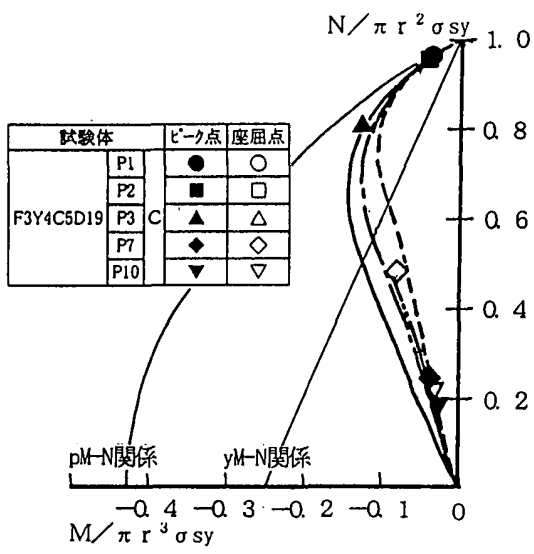

（b）横補強筋の軸力ー曲げモーメン関係

図 7 S/D の影響

\section{3 軸筋径の影響}

図9は、軸筋径を変数とした円形試験体の結果を比較したもの である。同図(a)によれば、各試験体の最大強度(ピーク点)時以降 の荷重一ひずみ関係は、軸筋の降伏荷重の差程度を相違とする、 ほぼ同様な曲線となっている。また、 $\delta \mathrm{max}-\varepsilon \mathrm{c}$ 関係も類似なも のとなっているが、これは、横補強筋が同一で、コンファインドコン クリートとしての特性が同じであることに起因すると考えられる。一 方、軸筋の横方向変位および軸ひずみが同じ場合、軸筋径が大 なる程、曲げ変形による最外縁ひずみも大となるため、最外縁ひ ずみが増加から減少に転ずる時点である座屈時は早期に現れる と推測される。しかし、本実験では、軸筋の座屈時ひずみにおよ ぼす軸筋径の影響は明確ではなく、その值はほぼ同程度のもの であった。

\section{$4.4 \sigma$ syの影響}

図10に、横補強筋降伏強度を変数とした円形試験体の結果を 比較する。同図(a)によれば、軸笳の座屈時ひずみは、横補強筋 の降伏強度が高い場合の方が小となる傾向がみられた。この原 


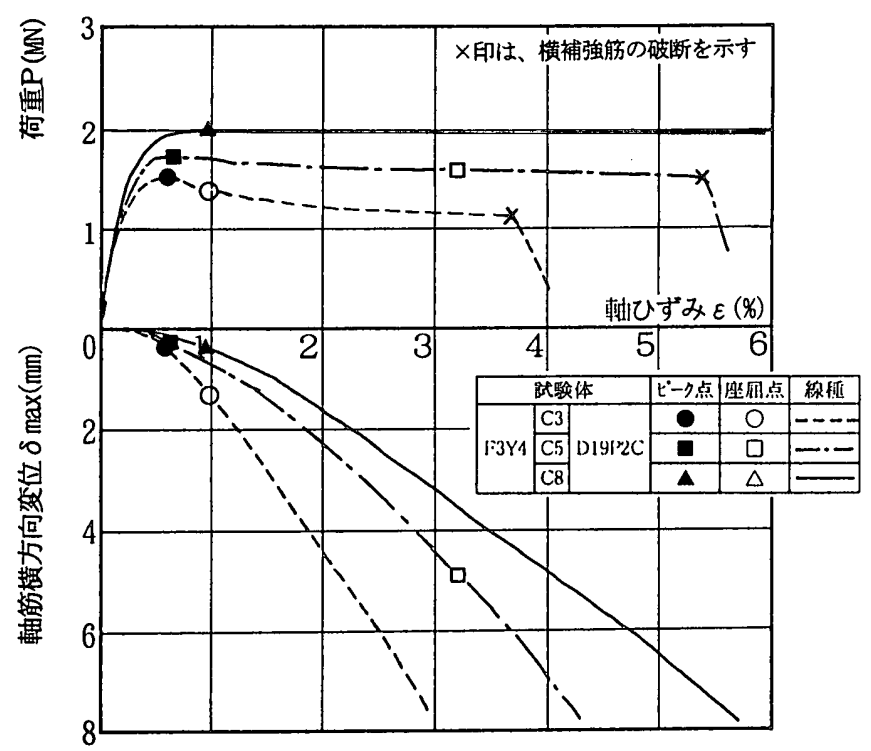

（a）荷重一軸ひずみ一軸筋横方向変位関係

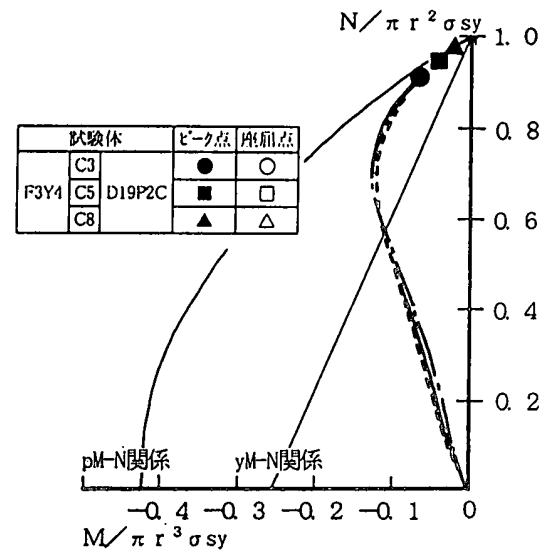

（b）横補強筋の軸力ー曲げモーメン関係

図 8 Ps $\sigma$ sy の影響

因として次のようなことが考えられる。Ps $\sigma$ sy が同量の場合、横補 強筋の降伏強度が高くなると、横補強筋の径が小となるため、軸 筋の横方向変形に対する抵抗性剛性が小さくなる。また、同図 (b)に示されるように、降伏ひずみが大となるため、軸筋の座屈時 においても $\sigma$ sy が $1300 \mathrm{Mpa}$ 級では横補強筋断面は全塑性状態 に達しておらず、全塑性に対する効率の低いことなどが考えられ る。

\section{$4.5 \mathrm{Fc}$ の影響}

プレーンコンクリートでは強度が大になると、荷重－軸ひずみ 関係は弾性的なものとなり、圧縮破壊近傍での横方向ひずみも 小となる。また、破壊は脆性的に起こり横方向ひずみは急增する ことが示されている ${ }^{19)}$ 。図11は、横補強笳が同一でコンクリート強 度を変数とした円形試験体の結果を比較したものである。同図(a) によれば、コンクリート強度が大なるとき程、座屈時ひずみは小と なる傾向がみられる。コンクリート強度が $30 \mathrm{MPa}$ 級の場合、試験体 の最大強度(ピーク点)時で横補強筋断面の $(\mathrm{M}, \mathrm{N})$ 応力状態は全 塑性に達して、軸筋の横方向変形を十分に拘束しており、このと

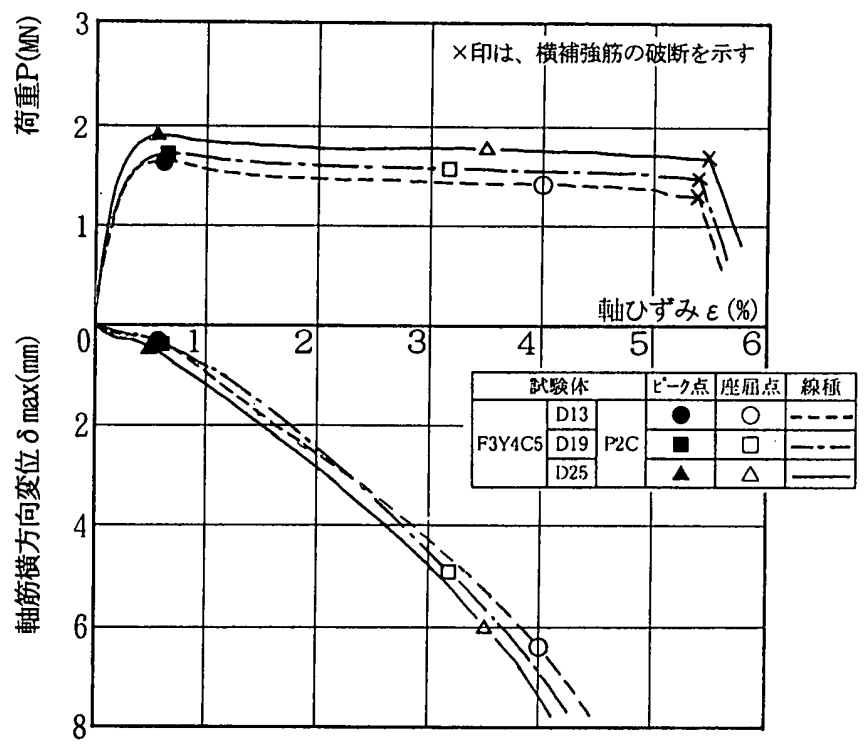

（a）荷重一軸ひずみ一軸筋横方向変位関係

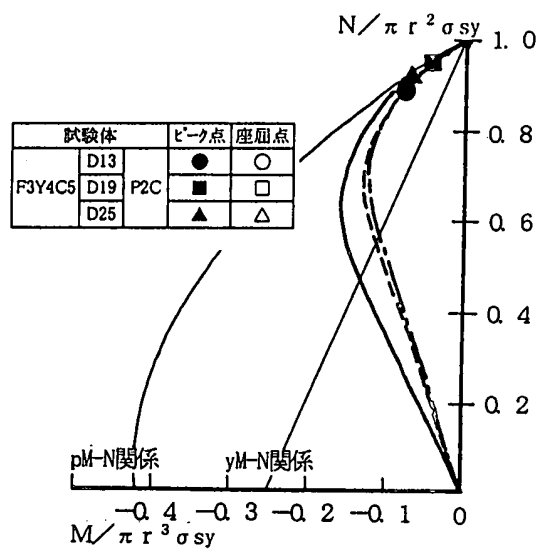

（b）横補強筋の軸力ー曲げモーメン関係

図 9 軸筋径の影響

きの座屈時ひずみは3\%にも達する。

これに対し、コンクリートが $90 \mathrm{MPa}$ 級の場合、試験体の最大強 度時および軸筋の座屈時においても軸筋の横方向変形が小さい ため、同図(b)に示されるように、横補強笳断面に作用する軸力、 言い換えれば横補強筋による拘束力は小さい。さらに、試験体の 破壊は脆性的に生じて、軸筋の横方向変形の軸ひずみに対する 増加率が急増するため、軸筋の座屈時ひずみは、試験体の最大 強度時ひずみと同程度のものとなっている。このことは、軸筋の座 屈防止の規定には、横補強筋の特性だけでなくコンクリート強度 の影響も考慮する必要のあることを示唆している。

\section{6 横補強筋形状の影響}

横補強筋の拘束効果は、横補強筋に曲げモーメントが作用す る角形横補強筋に比べ、フープテンションとなる円形横補強筋の 方が優れていることが示されている20)。図12は、横補強筋量 (Ps $\sigma \mathrm{sy})$ が同一で、横補強筋形状を変数とした試験体の結果を比 較したものである。なお同図で、円形試験体の荷重が角形試験 体に比べ低いのは、試験体断面積が小さいためである。同図に 


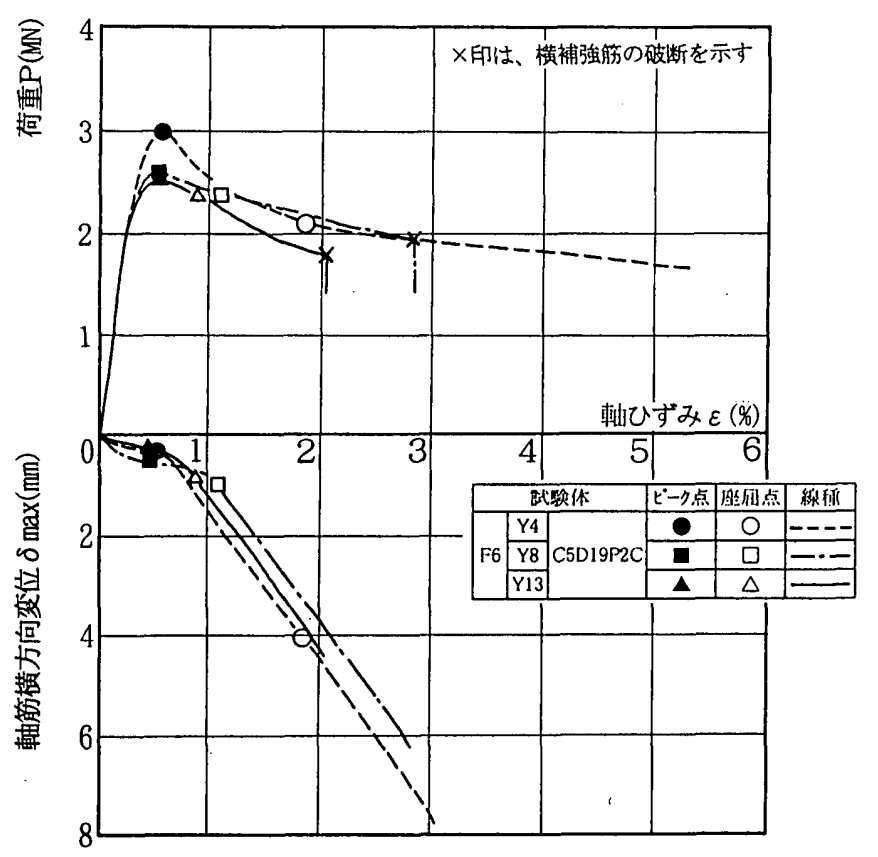

（a）荷重一軸ひずみ一軸筋横方向変位関係

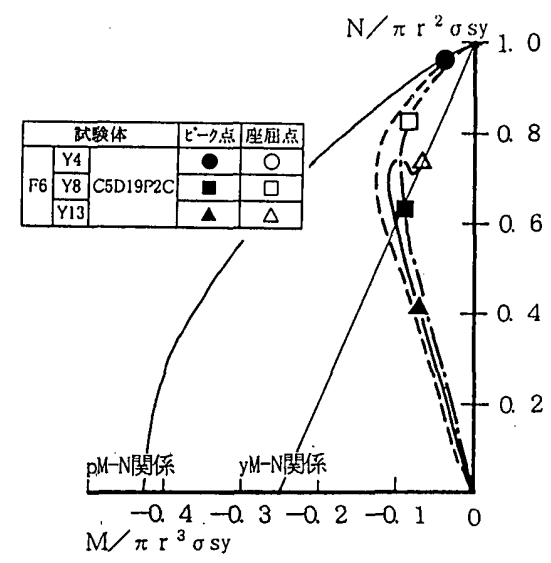

（b） 横補強笳の軸力ー曲げモーメト関係

図 $10 \quad$ o sy $の$ 影響

よれば、横補強筋形状が口型の場合、最大強度(ピーク点)直後 に急激な耐力低下を生じ、また、軸ひずみに対し軸筋の横方向 変形も急增するため、軸筋の座屈時ひずみは小さい。これに対し、 囲型の場合、サブフープの存在によってコンファインドコンクリート の性能が向上して、軸筋の横方向変形が抑制されるため、軸筋 の座屈時ひずみは増大し、冈形補強笳のそれに近づく傾向がみ られた。同一の横補強筋量 (Ps $\sigma$ sy) および横補強筋間隔比 (S/D) であっても、横補強筋形状が口型、囲型、およびO型と、 コンファインドコンクリートとしての性能を一層改善させるものとな る程、座屈時ひずみは大となる傾向がみられた。このことは、軸筋 の座屈防止のための配筋詳細は、コンファインドコンクリートの性 能と関連づけて考える必要のあることを示している。

\section{5. 結論}

主筋の座屈は、コンクリート構造における曲げ部材の終局破壊 に対する1つの重要な要因である。本研究では、主筋座屈に関

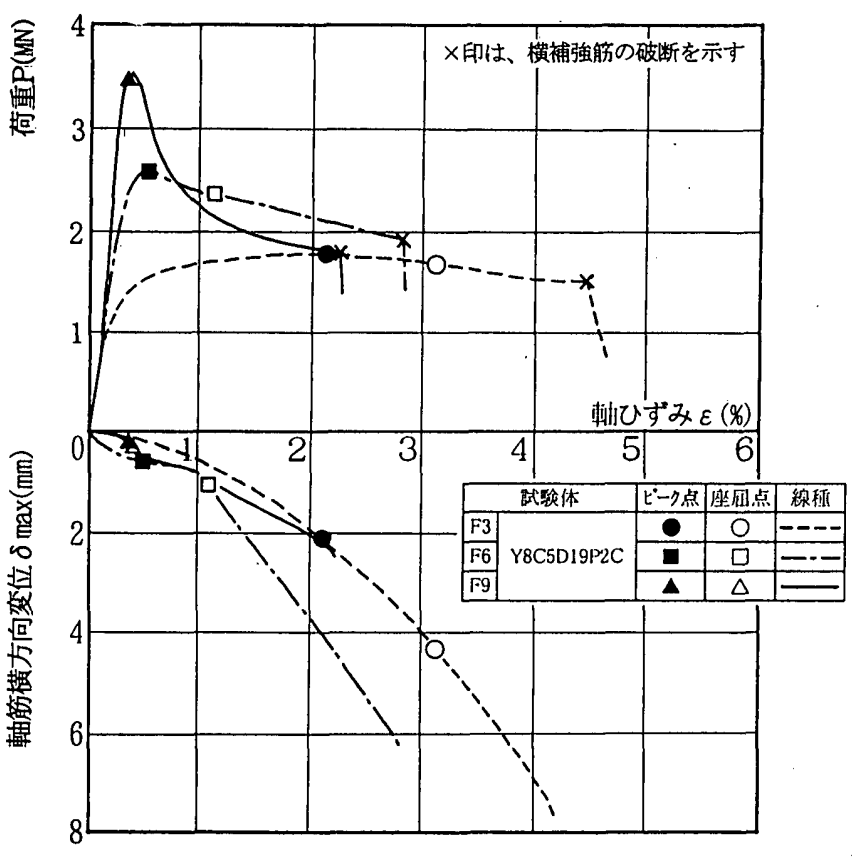

（a）荷重一軸ひずみー軸筋横方向変位関係

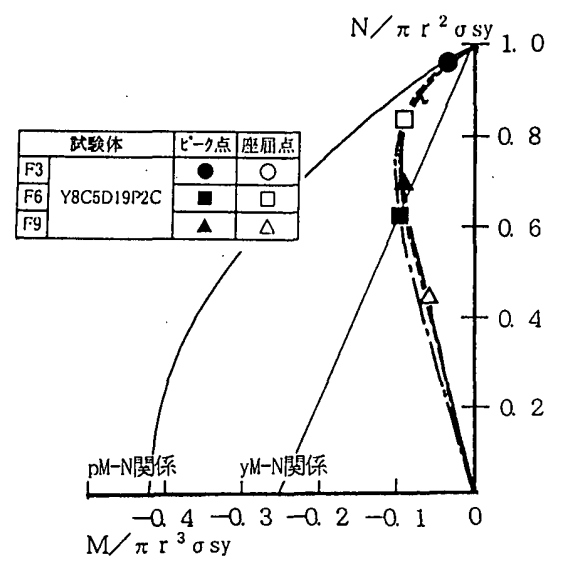

（b）横補強筋の軸力ー曲げモーメン関係

図 11 Fc の影響

する基礎資料を得るため、コンファインドコンクリート内に配筋され た圧縮軸筋の単調圧縮荷重下での座屈時ひずみにおよぼす諸 要因、すなわち、横補強筋の間隔、量、降伏強度、形状、および 軸筋径とコンクリート強度の影響を調べた。得られた結果を以下 に示す。

1)軸筋断面の最外縁ひずみが戻り始めて、負担軸力が减少する という明確な物理的意味を持つ時点を座屈時と定義し、各試 験体において測定した試験体の軸ひずみ一軸筋の横方向変 形関係から、同時点を判定する方法を示した。

2)座屈時は、軸筋の横方向変形に大きく依存するので、同変形 が急增する、試験体の最大荷重以降において生じた。

3)座屈時ひずみは、取り上げた諸要因によって次のような影響を 受けた。

a)横補強筋の間隔比(S/D)が小さくなると、またその量(Ps $\sigma$ sy) が大きくなると、横補強筋がコンクリートを有効に拘束して、軸 筋の横方向変形 $(\delta \max )$ は小となるため、座屈時ひずみは増 


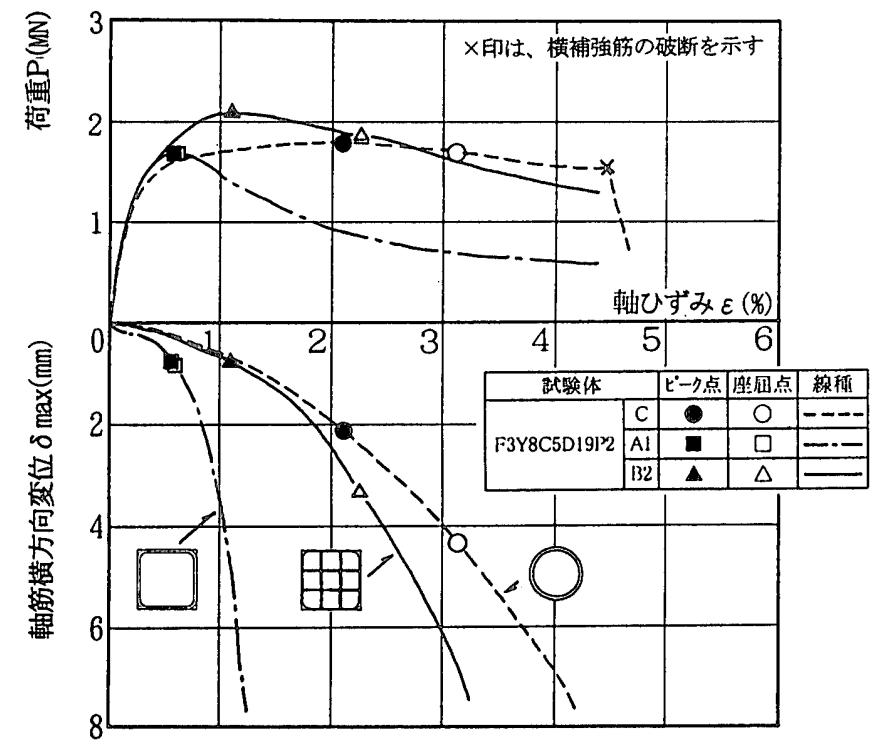

荷重一軸ひずみ一軸筋横方向変位関係

図 12 横補強筋形状の影響

大した。

b)座屈時ひずみにおよぼす軸筋径の影響は明確ではなかっ た。

c)横補強筋のS/DとPs $\sigma$ syが同じでも、降伏強度が低くて太い 横補強笳をもつ試験体の方が、高くて細い横補強筋をもつ 試験体の場合より若干大きい座屈時ひずみを示した。

d)同一の横補強筋の場合でも、コンクリート強度が高い場合ほ

ど、同じ軸ひずみに対する横方向変形は大となり、座屈時ひ ずみは小となった。

e)横補強筋の間隔比(S/D)、および量(Ps $\sigma$ sy)が同一で、横補 強筋形状のみが異なるとき、円形横補強筋の場合の座屈時 ひずみは、角形横補強筋の場合のそれに比べ大きい。角形 横補強筋の場合、サブタイおよびサブフープなどがあって、 コンファインドコンクリートとしての性能が向上する場合の方 が座屈時ひずみは大となった。

4)座屈防止のための現行の諸規定では、横補強筋の間隔（例 えば、主筋径の整数倍など) および量などを独立して与えるに 過ぎないものが多い。しかし、軸筋の座屈時ひずみは、横補強 筋の形状、降伏強度およびコンクリート強度によっても大きな 影響を受ける。これらの要因は、軸筋の横方向変形と密接に 関係するコンファインドコンクリートについての主影響要因であ ることから、座屈防止に関する配筋規定は、同コンクリートの性 能と関連づけて与えるべきものと考えられる。

\section{謝辞}

本研究に際しご助力を得た、岩井 潔君(現 竹中工務店)、な らびに横補強筋製作について多大なご援助を頂いた高周波熱 鍊(株)に、謝意を表します。

\section{参考文献}

1) NZS3101: Code of Practice for the Design of Concrete Structures, 1982, 1995

2）日本建築学会:プレストレス鉄筋コンクリート(III種PC)構造設計・施 工指針·同解説、pp.132-143，1986

3）日本建築学会: 建築耐霞設計における保有耐力と変形性能、 pp.507-525, 1990

4）鈴木計夫、中塚佶、岸本一蔵:鉄筋コンクリート柱部材の曲げ勒性と 横拘束 (コンファインド)補強筋量, 材料, 第40巻, 第456号, 1991年

5）鈴木計夫、中塚佶、阿波野昌幸:コンクリートはり部材断面の曲げ終 局限界点に関する研究、(その1)各種終局域指標点と提案する曲げ 終局限界点の存在メカニズム、日本建築学会棈造系論文集,1988

6）小柳洽、六郷恵哲、山本智志、近藤吉信:圧縮を受けるコンクリート 中の鉄筋の座屈性状、土木学会 第44回年次学術講演会講演梗 概集, 1989.10

7）井上晋、宮川豊章、藤井学: $\mathrm{RC}$ 部材中の軸方向鉄筋の座屈に関 する実験的検討、材料, 第40巻, 第456号, 1991年

8）丸山久一、趋唯堅、清水敬二:RC柱の主筋座屈に関する基礎的研 究、コンクリート構造物の鞋性と配筋方法に関するシンポジウム論文 集, 1990.5

9）吉田徳雄、畑中重光、上田英明: RC柱·梁部材の圧縮笳の座屈開 始時ひずみについて、コンクリートエ学年次論文報告集, Vol.14, No2, 1992年

10）加藤大介:鉄筇コンクリート部材の主筋の座屈性状に関する研究、 日本建築学会構造系論文報告集, 1992.6

11）黒正清治、和田章、久保田英之:鉄筋コンクリート部材のかぶりコン クリート剥落後の主筋座屈性状の解析、日本建築学会 電子計算 機利用委員会, 第7回電子計算機利用シンポジュウム, 1985年

12）須田久美子、村山八洲雄、一宮利通、新保弘: 交番繰返し荷重下 における柱筋の座屈挙動、コンクリートエ学年次論文報告集, Vol.16, No.2, 1994年

13）鈴木計夫、中塚佶、長田省作、井上和政:円形横補強笳を用いたב ンファインドコンクリート内に配置された圧縮軸鉄筋の座屈性状、 ンクリート工学年次論文報告集, Vol.9-2,1987年

14）鈴木計夫、中塚佶、山口善史、正田隆啓:各種の形状の横補強筋 を用いたコンファインドコンクリート内における圧縮軸筋の座屈性状、 コンクリート構造物の鞋性と配筋方法に関するシンポジウム論文集, 1990.5

15）岩井潔、中塚佶、鈴木計夫、中川裕史:圧縮軸筋の座屈性状にお よぼす横補強筋の仕様およびコンクリート強度の影響、コンクリート 工学年次論文報告集, Vol.15, No.2, 1993年

16）鈴木計夫、中塚佶、吉田晴彦:円形補強筋を用いたコンファインドコ ンクリートの強度および変形特性、材料, 第34巻, 第376号, 1985年

17）日本建筑学会: 鉄筋コンクリート造建物の終局強度型耐震設計指 針·同解説, 1990年

18）上之園隆志、平石久廣、山本孝一:高強度 $R C$ による新時代の RC 構造; 高強度材料の特性一鉄筋一、建築技術, pp.64-71, 1994. 6

19）中塚佶、阪井由尚、中川裕史、鈴木計夫:高強度材料による円形コ ンファインドコンクリートの強度・変形特性、日本建築学会構造系論 文集, pp.129-138,1996.5

20）中塚佶、阪井由尚、菅田昌宏、斎藤駿三、鈴木計夫:コンファインド コンクリートにおける角形横補強筋の拘束機構、日本建築学会棈造 系論文集, pp.61-68,1997.2

（1996年 9 月 10 日原稿受理，1997年 2 月 25 日採用決定） 